\title{
Chemo-Preventive Effect of 1-Piperoyl Piperidine (Piperine) is Mediated Through Intrinsic Signaling Mechanisms in Human Prostate Cancer Cells (Pc-3) In Vitro
}

\author{
Mathangi ${ }^{1}$, Nalini $\mathrm{D}^{2}$, Ponnulakshmi $\mathrm{R}^{3}$, Monisha Prasad ${ }^{4}$, Lakshmi Priya ${ }^{5}$, Selvaraj $\mathrm{J}^{6 *}$, Prasannakumar $\mathrm{M}^{7}$, Naveen \\ Chander $\mathrm{K}^{7}$
}

\begin{abstract}
Background: Prostate cancer is a heterogeneous disease and it is second deadliest malignancy in men and the most commonly diagnosed cancer among men. Current chemo-therapies are limited due to considerable side effects. Recently, many kinds of bioactive phytochemicals have contributed significantly to developing new therapies for chemo-resistant prostate cancer due to their structural diversity. Piperine, a natural alkaloid found in the fruit of black (Piper nigrum Linn) and long (Piper longum Linn), has shown antitumor activities toward various cancer cell lines. However, the antitumor effects of piperine on intrinsic and extrinsic signaling mechanisms in breast cancer has not been elucidated so far. The study aimed to assess the anticancer activity of piperine in human prostate cancer cells through intrinsic signaling pathways. Methodology: Prostate cancer (PC3) cells were treated with different concentrations of piperine $(100 \& 200 \mu \mathrm{g} / \mathrm{ml})$ to analyzeBcl-2, p53, case pase-3 and caspase- 9 protein expression in PC-3 cells. Cell viability was done using MTT in order to find the optimal dose. Results: MTT assay exhibited that piperine showed cell death at the concentration of 100 and $200 \mu \mathrm{g}$. It significantly decreased the mRNA and protein expression of anti-apoptotic proteins ( $\mathrm{Bcl}-2$ and $\mathrm{p}-\mathrm{Bcl}-2$ ) and increased the
\end{abstract}

Significance | Piperine can be considered as a potential phototherapeutic drug for the treatment of prostate cancer.

${ }^{*}$ Correspondence: Selvaraj J, Department of Biochemistry, Saveetha Dental College and Hospitals, Saveetha Institute of Medical and Technical Sciences, Chennai, India Email: jselvaendo@gmail.com

Editor Fazlul Huq, Editor-in-Chief at Journal of Angiotherapy. and accepted by the Editorial Board December 08, 2021 (received for review November 23, 2021) levels of $\mathrm{p} 53$, casepase- 3 and 9 protein expression in both concentrations used. Conclusion: Our present findings show that piperine induces apoptosis in PC-3 cells by inhibition the expression of anti-apoptotic proteins with concomitant increase in the tumor suppressor proteins effectively. Hence, piperine can be considered as a potential phototherapeutic drug for the treatment of prostate cancer which may lead to clinical utility.

Key Words: Piperine, Prostate cancer, Intrinsic signaling, PC-3 cells

\section{Introduction}

Cancer is the second leading explanation of death globally and is liable for an estimated 9.6 million deaths in 2018. Globally, about 1 in 6 deaths has been found in cancer. It is a major health issue in all countries due to its growing prevalence, mortality rate, and cost-effective treatment in both genders and ages(Atanasov et al.,2015, Babu S et al., 2020). Prostate cancer is a heterogeneous disease, and it is the second deadliest malignancy in men and the most commonly diagnosed cancer among men (Bang, J. 2019). Early perception of prostate cancer, like other diseases, is vital for better management and to stop mortality and reduce morbidity rates. Numerous studies are organized to gauge the danger of

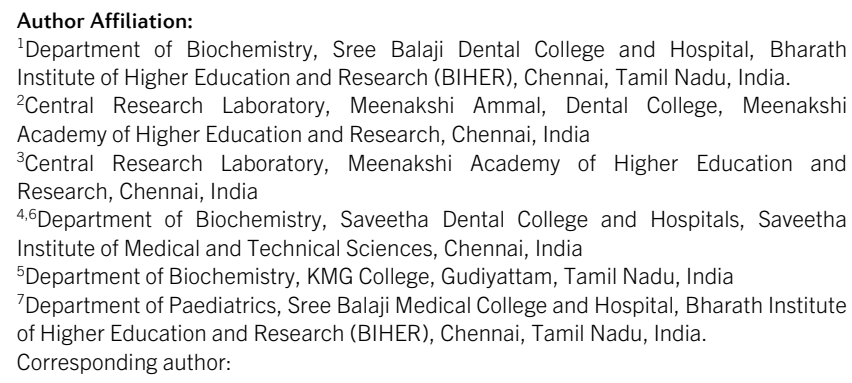

2207-8843/@ 2019 ANGIOTHERAPY, a publication of Eman Research Ltd, Australia. This is an open access article under the CC BY-NC-ND license. (http://creativecommons. or /licenses/by-nc-nd/4.0/) (https./publishing emanresearch.org). 
danger of prostatic adenocarcinoma-supported signs and symptoms (Brawer MK2006). Noticeably, more successful therapies are needed for many common cancers. However, the standard cancer research would be to identify either pharmacologic or lifestyle interventions that could prevent the onset of prostate cancer (Chandrasekaran Kirubhanand et al .2020). Studies have shown that some natural foods' intake decreases the risk of various dreadful diseases including diabetes, cancer, etc (Cryns V, Yuan J 1988 ,Desai AG et al.,2008,Devarajan N et al.,2021,D'Hooge,et al .,1996,Fischer U,Schulze-Osthoff K 2005)

Intrinsic apoptotic pathway is mainly governed by Bcl- 2 family proteins. This family contains both pro- and anti-apoptotic proteins. The anti-apoptotic protein $\mathrm{Bcl}-2$ is an oncogene that contributes to neoplastic progression by enhancing tumor cell survival through inhibition of apoptosis. In prostate cancer, this $\mathrm{Bcl}-2$ is overexpressed, leading to metastatic prostate cancer progression through inhibition of apoptotic cell death (Hanahan D, Weinberg RA 2000). This Bcl-2 overexpression also causes resistance to heat-shock stress, several chemotherapies and radiotherapy(Hema, Selvaraj J,2019).Although great advancements have been made in treating and controlling cancer progression, significant deficiencies and space for improvement remain. Several undesired side effects sometimes occur during chemotherapy(Henderson BE, Feigelson HS.2000). Compared with synthetic compounds, natural products provide inherent larger-scale diversity and have been the major resource of bioactive agents for new drug discovery(Isaacs JT et al., 1992).From a research point of view, natural products are rapidly being utilized as a source for drug discovery and development because of their comparatively safe and low cost. Anticancer agents from natural sources have a long history in folk medicine, and it has been combined into traditional and allopathic medicine. Nowadays, approximately $28 \%$ of modern medicines are derived from medicinal plants (Janardhanan S et al., 2020,Jayaraman S et al.,2021 Khan KH,et al.,2015,Kim, H. Get al., 2012,KumarS, et al 2017). There are several drugs derived from the plant origin are used in market to treat cancer which includes vinca alkaloidsvinblastine and vincristine, epipodophyllotoxins (etoposide, teniposide), taxanes (paclitaxel, docetaxel), and camptothecin derivatives (topotecan, irinotecan) (Li.S, Wang et al., 2017).

Medicinal plants are at interest to the field of novel drug development, as most drug industries depend on medicinal plants to produce novel bioactive compounds. Piperine, a major alkaloidal constituent presented in black (Piper nigrum Linn) and long (Piper longum Linn), has been accepted extensively as one of the most common spices used in food and folk medicine worldwide(Mittal, R.; Gupta, R. L 2007,Nair R et al .,2013). A load of evidence from previous studies demonstrated that it possesses a wide range of pharmacological actions, such as anticonvulsant (Nalini D et al., 2018), antimicrobial (Ouyang, D. Y et al., 2013), antioxidant (PonNivedha $\mathrm{R}$ et al .2015), neuroprotective(Ponnulakshmi R et al., 2018 ), anti-inflammatory, and anti-arthritic activities(Reed JC, Pellecchia M. 2005 ).Notably, it is also known to prevent tumor development in various cancers, including breast cancer, lung cancer, prostate cancer, gastric cancer, rectal cancer and so on (Salie, F et al., 1996 ,Selvaraj J,et al., 2020). Additionally, earlier studies showed that colchicine administration could prevent and delay the development of aflatoxin and CCl4-induced cancer in rats without significant side effects(Selvendiran et al., 2003). However, the anticancer effect of piperine in prostate cancer has not been elucidated. Therefore, our goal of this study is to investigate whether piperine has inhibitory effect on the growth of prostate cancer cells in vitro and further explore the underlying molecular mechanism.

\section{Materials and Methods}

\section{Chemical and Reagents}

All the chemicals used in this study were of extra pure and analytical grade. CA and dimethyl sulfoxide (DMSO) and 3-(4,5dimethylthiazol-2-yl)-2,5- diphenyltetrazolium bromide (MTT) were purchased from Sigma Chemical Pvt., Ltd. (St. Louis, MO., USA), polyvinylidenedifluoride (PVDF) membrane was purchased from Millipore (Billerica, Massachusetts, USA). Trypsin-EDTA, fetal bovine serum (FBS), antibiotics-antimycotics, Roswell Park Memorial Institute (RPMI) medium, and phosphate-buffered saline (PBS) were purchased from Gibco, United States. Primary antibodies Bcl-2, p-Bcl-2, p53, case pase-3 and caspase-9 were purchased from cell signaling (Danvers, Massachusetts, United States) and Santa Cruz Biotechnology (Texas, United States). The secondary antibodies, horseradish peroxidase (HRP) conjugated rabbit anti-mouse IgG, and goat-anti-rabbit IgG were obtained from Santa Cruz Biotechnology (Texas, United State).

\section{Procurement and maintenance of PC-3Cell line}

PC-3 cell lines were obtained from the National Centre for Cell Science (Pune, India). The cells were grown in T-25 culture flasks in RPMI medium supplemented with $10 \%$ FBS with $1 \%$ penicillin/streptomycin and $1 \%$ amphotericin B. Cells were maintained at $37^{\circ} \mathrm{C}$ in a humidified atmosphere containing $5 \%$ $\mathrm{CO}_{2}$. On attaining the confluence, the cells were trypsinized and plated.

\section{Cell viability test}

The cell viability assay was performed by MTT assay, which determines mitochondrial activity in living cells. Cells were seeded in a 96-well plate at a density of $5 \times 10^{4}$ cells/well and incubated for $24 \mathrm{~h}$ at $37^{\circ} \mathrm{C}, 5 \% \mathrm{CO}_{2}$ incubator. After attachment, cells were washed with $\mathrm{PBS}$ and then incubated with serum-free medium for 6-12 h. EA was dissolved in DMSO with different concentration 
$(100 \& 200 \mu \mathrm{g} / \mathrm{ml})$ and added to the cells. After the treatment period, $20 \mathrm{ml}$ medium was removed and $20 \mathrm{ml}$ of MTT was added and incubated for $30 \mathrm{~min}$. Then, $100 \mathrm{ml}$ of DMSO was added to solubilize the crystals and kept in dark for 10 minutes. The intensity of color development was measured at $570 \mathrm{~nm}$ in ELISA reader. The cell viability was calculated as follows: Cell viability $=$ absorbance of treated cells/absorbance of control cells $\times 100 \%$. Cell lysate preparation PC-3cells were placed in a Petri dish of $100 \mathrm{~mm}$ $\times 20 \mathrm{~mm}$ at a density concentration of $1 \times 10^{4}$ cells/Petri dish and grown in RPMI medium, respectively, with 10\% FBS. After $24 \mathrm{~h}$ ( 70-80\% confluent), both the cells were treated with DAM (10 and $100 \mathrm{mM} / \mathrm{ml}$ ) for $24 \mathrm{~h}$. At the end of the treatment, cells were washed once with ice-cold PBS and added $300 \mathrm{ml}$ of ice-cold RIPA buffer with protease inhibitors. The Petri dishes were placed on ice and left on a shaker rocking for $2 \mathrm{~min}$. Cell lysates were collected into a $1.5-\mathrm{ml}$ tube and centrifuged at $14,000 \times \mathrm{g}$ for $10 \mathrm{~min}$ at $4^{\circ} \mathrm{C}$. The supernatant was separated and the protein concentration of supernatants was determined.

\section{Protein expression analysis}

\section{Preparation of cell lysate}

PC-3 cells were plated in a petri-dish of $100 \mathrm{~mm} 20 \mathrm{~mm}$ at a density concentration of $1 \times 10^{6}$ cells/petri-dish and grown in RPMI medium, respectively, with 10\% FBS. After $24 \mathrm{~h}(\sim 70-80 \%$ confluent), both the cells were treated with piperine $(100 \& 200 \mu \mathrm{g})$ for $24 \mathrm{~h}$. At the end of treatment, cells were washed with ice-cold PBS and added $300 \mathrm{ml}$ of ice-cold RIPA buffer with protease inhibitors. The petri-dishes were placed on ice and left on a shaker rocking for $2 \mathrm{~min}$. Cell lysates were collected into a $1.5-\mathrm{ml}$ tube and centrifuged at $14 \mathrm{x} 000 \mathrm{~g}$ for $10 \mathrm{~min}$ at $4^{\circ} \mathrm{C}$. The supernatants were separated and the protein concentration of supernatants was determined.

\section{Protein isolation and western blotting}

For protein isolation, $100 \mathrm{mg}$ of adipose tissue from control and experimental animals were used. To $100 \mathrm{mg}$ of adipose tissue, $1 \mathrm{ml}$ of buffer A ( $5 \mathrm{mM} \mathrm{NaN3}, 0.25 \mathrm{M}$ sucrose, $10 \mathrm{mM} \mathrm{NaHCO} 3$ ) was added, homogenized, and centrifuged at $1300 \times \mathrm{g}$ at $4{ }^{\circ} \mathrm{C}$ for 10 min. The supernatant was separated and again centrifuged at $4{ }^{\circ} \mathrm{C}$ for $15 \mathrm{~min}$ at $12,000 \times \mathrm{g}$. The final supernatant was specimened as a total protein to assess the post-receptor insulin signaling molecules. By using sodium dodecyl sulfate-polyacrylamide gel electrophoresis (10\% gel), The lysate proteins $(50 \mu \mathrm{g} / \mathrm{lane})$ were separated and transferred to polyvinylidenedifluoride (PVDF) membrane (Bio-Rad Laboratories Inc) by electroblotting. 5\% of non-fat dry milk was used to block the membranes and tagged with the primary antibodies (1:1000 dilutions). The membrane was subjected to repeated wash with TBS- $\mathrm{T}$ for three times and incubated with 1:5000 dilution of horseradish peroxidaseconjugated rabbit-anti-mouse or goat-anti-rabbit secondary antibodies (GeNei, Bangalore, India) for $1 \mathrm{~h}$. After incubation, the membrane was again subjected to repeated wash with TBS and TBS-T three times. The protein bands were visualized using a Chemiluminescence detection system (Thermo Fisher Scientific Inc., Waltham, MA, USA), the specific signals were found and protein bands were captured and quantified by Chemidoc and Quantity One image analysis system Bio-Rad Laboratories, CA respectively. Later, themembrane was incubated at $50^{\circ} \mathrm{C}$ in stripping buffer (50 ml, containing6 $2.5 \mathrm{mM}$ of Tris- $\mathrm{HCl}$ (pH 6.7), $1 \mathrm{~g}$ of SDS and $0.34 \mathrm{ml}$ of $\beta$-mercaptoethanol) for $30 \mathrm{~min}$. Then, the membranes were reprobed with $\beta$ - actin antibody (1:5000). $\beta$ actin was used as invariant control.

\section{Statistical Analysis}

Data were expressed as mean \pm standard error of the mean. Statistical analyses were performed using one-way ANOVA followed by Duncan's tests to compare treatment and control values using the Statistical Package for Student version 17.0 (SPSS Inc., Chicago, IL) software $\mathrm{p}<0.05$ was considered statistically significant.

\section{Results}

\section{Effect of piperine on the cell viability in PC-3 cells}

Piperine reduced the viability of PC-3 cells in a dose-dependent manner $(25,50,100$ and $200 \mu \mathrm{M})$ concentration. 25 and $50 \mu \mathrm{g}$ dose did not respond in cell growth inhibition. However, the 100 and $200 \mu \mathrm{g}$ dose could significantly reduce cell growth $(\mathrm{p}<0.05)$. Hence, $100 \mu \mathrm{g}$ and $200 \mu \mathrm{g}$ concentrations were used for further analysis of protein expression of apoptosis signaling cascade (Fig.1).

Effect of piperine on $\mathrm{Bcl}-2$ and $\mathrm{p}-\mathrm{Bcl}-2$ protein expression in PC-3 Cells

The protein expression analysis was performed to examine the status of intracellular signaling molecules in the piperine-treated cells. Piperine treatment significantly decreased $(p<0.05)$ the antiapoptotic proteins such as Bcl-2 and p-Bcl-2 (Figures 2).

Effect of piperine on $\mathrm{p53}$, Case pase- 3 and caspase-9 protein expression in PC-3 cells

Piperine treated PC-3 cells showed a significant increase $(p<0.05)$ in $\mathrm{p} 53$, casepase- $3 \& 9$ protein expression stating that piperine has a significant role in the regulation of tumor suppressor protein activation (Figure 3).

\section{Discussion}

Apoptosis is a critical process in cancer development. Evading apoptosis is one of the hallmarks of cancer. The apoptotic pathway plays a significant role in prostate cancer as well. Prostate cancer treatment initially starts with androgen withdrawal, where many of the cancer cells die through apoptosis. But in some cases, the cells derive resistance to this treatment and leads to metastatic prostate cancer (Srinivasan Perumal et al.,2018). Hence, in this 
study we aimed to manage this advanced stage of cancer by targeting apoptotic pathway. As we were targeting advanced stage of cancer, hormone-independent cell line PC-3 was selected for the study.

In the present study we investigated the intrinsic pathway of apoptosis induced by piperine in prostate cancer cells PC-3. In the present study, piperine effectively reduce the Bcl-2 mRNA expression suggesting that it induces apoptosis due to its potential antioxidant activity. In this regard, studies have shown that the anticancer property of Piper nigrumextract has rich in polyphenols and hydrolysable tannin derived compounds that act as antioxidants (Taneja, SC. Qazi, GN 2017). In addition, tannins from Piper nigrumhave been reported to prevent mutagenesis and lipid peroxidation in response to carcinogens and ROS.

Caspase- 3 is a vital member of the caspase family, a group of cysteine proteases that mediate apoptotic execution (Thun MJ et al., 2010). It can be activated by apoptotic signals from both death receptor and intracellular/mitochondrial pathways. Caspase-3 is a major effector caspase by cleaving numerous cell death substrates, leading to cellular dysfunction and destruction (Van LooG, Saelens X, Matthijssens F2006). Caspase-3 deficiency and downregulation have been associated with breast carcinogenesis (Xia Y et al 2015,Zielinski RR et al.,2013), suggesting caspase-3 could be a biomarker in cancer prevention and treatment. In the present study, piperine treatment significantly increased p53, caspase-3 and caspase- 9 mRNA expression. Furthermore, the present study proved that piperine induced activation of caspase- 3 and 9 might be mediated through initiation ofintrinsic apoptotic signaling pathway, thus piperine induces intrinsic pathway mediated apoptosis.

\section{Conclusion}

The current study proved that piperine strongly inhibits the growth of prostate cancer cells by interfering with the apoptotic pathway. It down-regulated the antiapoptotic proteins while upregulated the pro-apoptotic proteins and thereby paved the way to cell death. Furthermore, the caspase- 9 and caspase- 3 activation proved that piperine acts through intrinsic apoptotic pathway. Thus, piperine could be used as a therapeutic natural drug for treating prostate cancer. Further experiments through animal model and clinical trial will lead piperine to be a potent drug in future. 


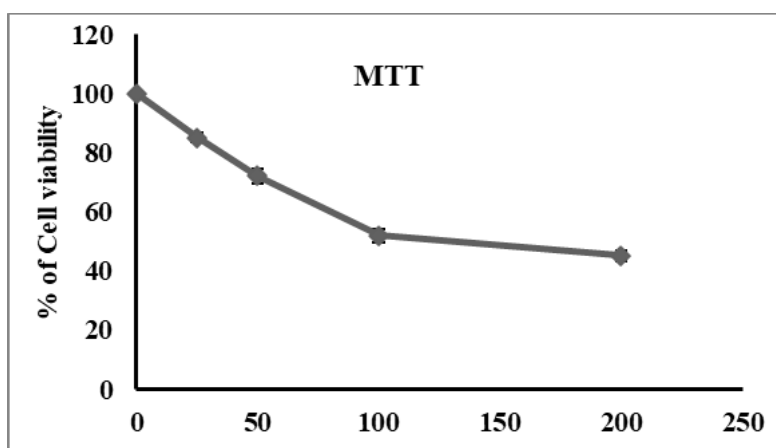

Piperine Concentration $(\mu \mathrm{M} / \mathrm{mL})$
Figure 1: Effect of Piperine on the viability of prostate cancer cells. PC-3 cells were cultured in RPMI medium supplemented with $10 \%$ FBS and incubated with indicated concentrations of DGT for $\mathbf{2 4} \mathrm{h}$. For cell viability assay, cells were exposed to different doses $(25,50,100$ and $200 \mu \mathrm{M})$ of piperine for $\mathbf{2 4} \mathrm{h}$. Piperine inhibits the growth (as determined by MTT assay) of human prostate cancer cells. Each bar represents the mean \pm SEM of five independent observations and the statistical significance between the control and the treated groups at $p<0.05$ level.
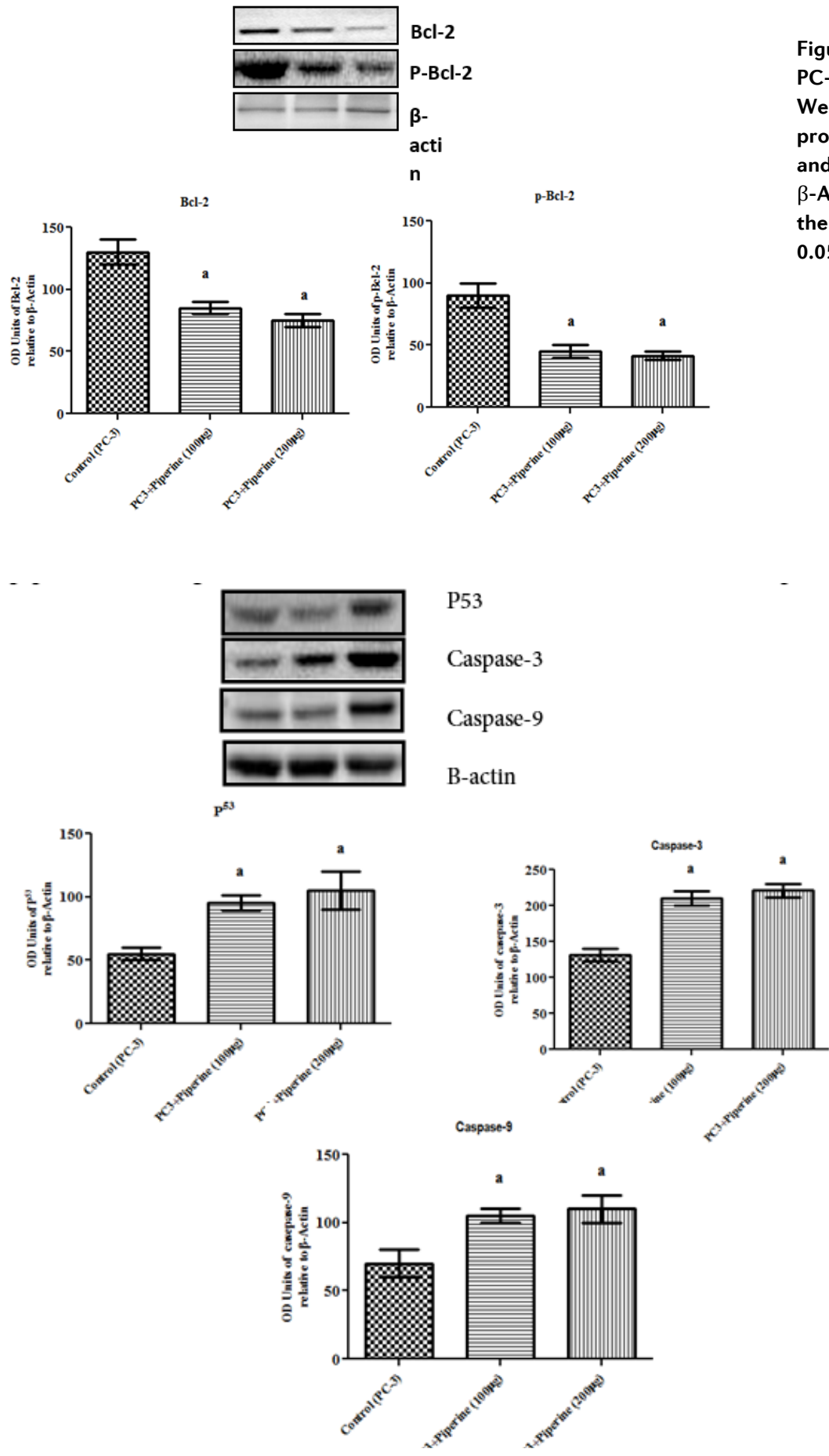

Figure 2: Effect of piperine on anti-apoptotic proteins in PC -3 cells. Protein expression was analyzed using the Western blotting method using specific antibodies and protein levels were quantified using densitometry analysis and expressed in relative intensity arbitrary unit. $\beta$-Actin was used as an internal control.Each bar represents the Mean \pm SEM of five observations. Significance at $p<$ 0.05 . a-compared with untreated cancer cells.
Figure 3: Effect of piperine on p53, Casepase-3 and Casepase-9 protein expression in PC-3 cells. Protein expression was analyzed using the Western blotting method using specific antibodies and protein levels were quantified using densitometry analysis and expressed in relative intensity arbitrary unit. $\beta$-Actin was used as an internal control. Each bar represents the Mean \pm SEM of five observations. Significance atp $<\mathbf{0 . 0 5}$. acompared with untreated cancer cells. 


\section{Author Contributions}

Mathangi Nalini D, Ponnulakshmi R conceived of the presented idea. Monisha Prasad, Lakshmi Priya MD, Selvaraj J, Prasannakumar M and Naveen Chanderen couraged and supervised the findings of this work. All authors discussed the results and contributed to the final manuscript

\section{Acknowledgment}

None declared

\section{Competing financial interests}

The author(s) declare no competing financial interests.

\section{References}

Atanasov AG, Waltenberger B, Pferschy-Wenzig EM, et al. 2015.Discovery and resupply of pharmacologically active plant-derived natural products: A review. Biotechno Adv.;33(8):1582-1614.https://doi.org/10.1016/j.biotechadv.2015.08.001

Babu S, Krishnan M, Rajagopal P, Periyasamy V, Veeraraghavan V, Govindan R, Jayaraman S. 2020.Beta-sitosterol attenuates insulin resistance in adipose tissue via IRS 1/Akt mediated insulin signaling in high fat diet and sucrose induced type-2 diabetic rats. Eur J Pharmacol.:15;873:173004 https://doi.org/10.1016/j.ejphar.2020.173004

Bang, J. S.; Oh, D. H.; Choi, H. M.; Sur, B. J.; Lim, S. J.; Kim, J. Y.; Yang, H. I.; Yoo, M. C. Hahm, D. H.; Kim, K. S.2009. Anti-inflammatory and antiarthritic effects of piperinein human interleukin $1 \beta$-stimulated fibroblast-like synoviocytes and in rat arthritis models. Arthritis Res Ther.:11;R49. https://doi.org/10.1186/ar2662

Brawer MK.2006. Hormonal therapy for prostate cancer. Rev Urol; 8:S1-9.

[dataset] Chandrasekaran Kirubhanand, Jayaraman Selvaraj, Umapathy Vidhya Rekha, Veeraraghavan Vishnupriya, Venkatachalam Sivabalan, Mathayan Manikannan, Devarajan Nalini, Periyasamy, Vijayalakshmi, Manikkam Rajalakshmi, Rajagopal Ponnulakshmi.2020. Molecular docking analysis of $\mathrm{Bcl}-2$ with $\begin{array}{lll}\text { phytocompounds. } & \text { Bioinformation..:0 16(6); }\end{array}$ https://doi.org/10.6026/97320630016468

Cryns V, Yuan J.1998. Proteases to die for. Genes Dev;12:1551-70 https://doi.org/10.1101/gad.12.11.1551

Desai AG, Qazi GN, Ganju RK, et al.2008. Medicinal plants and cancer chemoprevention. Curr Drug Metab.;9(7):581-591. https://doi.org/10.2174/138920008785821657

Devarajan N, Jayaraman S, Mahendra J, Venkatratnam P, Rajagopal P, Palaniappan H, Ganesan SK 2021. Berberine-A potent chemosensitizer and chemoprotector to conventional cancer therapies. Phytother Res. 2021; 1-19. https://doi.org/10.1002/ptr.7032

D'Hooge, R.,Pei, Y. Q., Raes, A,Lebrun, P.1996. Anticonvulsant 395 activity of piperine on 396 seizures induced by excitatory amino acid receptor agonists. ArzneimittelForschung:46;557-560
Fischer U, Schulze-Osthoff K.2005. Apoptosis-based therapies and drug targets. Cell Death Differ; 12:942-61. https://doi.org/10.1038/sj.cdd.4401556

Hanahan D, Weinberg RA. 2000. The hallmarks of cancer. Cell; 100:57-70. https://doi.org/10.1016/S0092-8674(00)81683-9

Hema, Selvaraj J, D.Nalini.2019. Hypolipidemic properties of Aloe vera in female Swiss albino mice. Drug Invention Today.: 12: 2377-2380.

Henderson BE, Feigelson HS.2000. Hormonal carcinogenesis. Carcinogenesis; 21:427-33. https://doi.org/10.1093/carcin/21.3.427

Isaacs JT, Lundmo PI, Berges R, et al.1992. Androgen regulation of programmed death of normal and malignant prostatic cells. J Androl; 13:457-64.

Janardhanan S, Mahendra J, Mahendra L, Devarajan Nalini.2020. Cytotoxic Effects of Mangosteen Pericarp Extracts on Oral Cancer and Cervical Cancer Cells. Asian $\begin{array}{llll}\text { Pac } & \text { Cancer 21(9):2577-2583. }\end{array}$ https://doi.org/10.31557/APJCP.2020.21.9.2577

Jayaraman S, Devarajan N, Rajagopal P, Babu S, Ganesan SK, Veeraraghavan VP, Palanisamy CP, Cui B, Periyasamy V, Chandrasekar K.2021. $\beta$-Sitosterol Circumvents Obesity Induced Inflammation and Insulin Resistance by downRegulating IKK $/$ NFF-KB and JNK Signaling Pathway in Adipocytes of Type 2 $\begin{array}{llll}\text { Diabetic } & \text { Rats. } & \text { 6;26(7):2101. }\end{array}$ https://doi.org/10.3390/molecules26072101

Khan KH, Blanco-Codessido M, Molife LR.2014. Cancer therapeutics: targeting the apoptotic pathway. Crit Rev OncolHematol;90: 200-19. https://doi.org/10.1016/j.critrevonc.2013.12.012

Kim, H. G.; Han, E. H.; Jang, W. S.; Choi, J. H.; Khanal, T.; Park, B. H.; Tran, T. P.; Chung, Y. C.; Jeong, H. G.2012. Piperine inhibits PMA-induced cyclooxygenase-2 expression through downregulating NF-kB, C/EBP and AP-1 signaling pathways in murine macrophages. Food Chem Toxicol.;50; 2342-2348. https://doi.org/10.1016/j.fct.2012.04.024

[dataset] KumarS, Singhal,V, RoshanR, Sharma A,Rembhotkar GW,Ghosh B. 2007.Piperine inhibits TNF- $\alpha$ induced adhesion of neutrophils to endothelial monolayer through suppression of NF-kB and IкB kinase activation. Eur J Pharmacol.:575; 177-186. https://doi.org/10.1016/j.ejphar.2007.07.056

Li.S, Wang, C, Wang, M., Li, W. Matsumoto K.,Tang Y.2006. Antidepressant like 393 effects of piperine in chronic mild stress treated mice and its possible mechanisms. 394 Life Sci. 2007, 80, 1373-1381, DOI: 10.1016/j.Ifs..12.027. https://doi.org/10.1016/j.lfs.2006.12.027

Mittal, R.; Gupta, R. L.2000. In vitro antioxidant activity of piperine, Methods Find Exp. Clin. Pharmacol.: 22;271-274. https://doi.org/10.1358/mf.2000.22.5.796644

[dataset] Nair R, Withington J, Ghos S, Henderson A.2013. Early detection and patient risk stratification in prostate cancer. In: Ashutoshtewari, ed. Prostate cancer: a comprehensive perspective. London, Heidelberg, New York, Dordrecht: 
Springer;34-45.https://doi.org/10.1007/978-1-4471-2864-9_34

https://doi.org/10.1007/978-1-4471-2864-9_34

Nalini D; Selvaraj J; Senthil Kumar G. 2020. Herbal Nutraceuticals - Safe and potent therapeutics to battle tumor hypoxia. Journal of Cancer Research and Clinical Oncology.: 146: 1-18. https://doi.org/10.1007/s00432-019-03068-x

Ouyang, D. Y.; Zeng, L. H.; Pan, H.; Xu, L. H.; Wang, Y.; Liu, K. P.; He, X. H.2013. Piperine inhibits the proliferation of human prostate cancer cells via induction of cell cycle arrest and autophagy, Food Chem Toxicol.: 60;424-430. https://doi.org/10.1016/j.fct.2013.08.007

PonNivedha R, Selvaraj J, Lalitha KG, Rajalakshmi M.2015. Effects of dihydroxygymnemic triacetate (DGT) on expression of apoptosis associated proteins in human prostate cancer cell lines (PC3). J Recept Signal Transduct Res.;35(6):605612. https://doi.org/10.3109/10799893.2015.1034368

Ponnulakshmi R, Shyamaladevi B, Vijayalakshmi P, Selvaraj J. 2019. In silico and in vivo analysis to identify the antidiabetic activity of beta sitosterol in adipose tissue of high fat diet and sucrose induced type-2 diabetic experimental rats. Toxicol Mech

Methods.;29(4):276-290

https://doi.org/10.1080/15376516.2018.1545815

Reed JC, Pellecchia M.2005. Apoptosis-based therapies for hematologic malignancies. Blood;106:408-18. https://doi.org/10.1182/blood-2004-07-2761

Salie, F.; Eagles, P.FK., Leng, H.M.J.1996. Preliminary antimicrobial screening of four South African Asteraceae species. J Ethnopharmacol:52;27-33. https://doi.org/10.1016/0378-8741(96)01381-5

[dataset] Selvaraj J, Ponnulakshmi R, Abilasha S, Nalini D, Vijayalakshmi P, Vishnupriya V, Mohan SK.2020. Docking analysis of importin-11 homology model with the phyto compounds towards colorectal cancer treatment. Bioinformation. 16(2):153-159. https://doi.org/10.6026/97320630016153

Selvendiran, K,Singh, JPV,Krishnan, K B ,Sakthisekaran, D. 2003.Cytoprotective effect of piperine against benzo [a] pyrene induced lung cancer with reference to lipid peroxidation and antioxidant system in Swiss albino mice. Fitoterapia:426 109115. https://doi.org/10.1016/S0367-326x(02)00304-0

Srinivasan Perumal, Kulanthaivel Langeshwaran, Jayaraman Selvaraj, Rajagopal Ponnulakshmi, B Shyamaladevi, MP Balasubramanian.2018.Effect of diosmin on apoptotic signaling molecules in $\mathrm{N}$-nitrosodiethylamine-induced hepatocellular carcinoma in experimental rats. Molecular and cellular biochemistry.:449(1); 27-37. https://doi.org/10.1007/s11010-018-3339-3

Taneja, SC. Qazi, GN.2007. Bioactive Molecues in Medicinal Plants: A perspective in their therapeutic action, in Drug discovery and development. Chorghade, MS., editor. John Wiley and Sons, Inc;:. 1-50. https://doi.org/10.1002/9780470085226.ch17
Thun MJ, De Lancey JO, Center MM, et al.2010. The global burden of cancer: priorities for prevention. Carcinogenesis; 31:100-10. https://doi.org/10.1093/carcin/bgp263

Van LooG, Saelens X, Matthijssens F et al.2002. Caspases are not localized in mitochondria during life or death. Cell Death Differ;9:1207-11. https://doi.org/10.1038/sj.cdd.4401101

Xia Y, Khoi, PN,Yoon, H.J,Lian, SJ,oo, YE, Chay, KO, Kim K,Jung, Y D.2015 Piperine inhibits IL-1 $\beta$-induced IL-6 expression by suppressing p38 MAPK and STAT3 activation in gastric cancer cells. Mol Cell Biochem.: 398;147-156. https://doi.org/10.1007/s11010-014-2214-0

Yaffe, PB, Doucette CD, WalshM., Hoskin, DW.2013. Piperine impairs cell cycle progression and causes reactive oxygen species-dependent apoptosis in rectal cancer cells, $\quad$ Exp Mol Pathol.; 94: 109-114. https://doi.org/10.1016/j.yexmp.2012.10.008

Yuan H, Ma Q, Ye L, Piao G.2016. The Traditional Medicine and Modern Medicine from $\begin{array}{lll}\text { Natural } \quad \text { Products. } & \text { Molecules.; }\end{array}$ https://doi.org/10.3390/molecules21050559

Zielinski RR, Eigl BJ, Chi KN.2013. Targeting the apoptosis pathway in prostate cancer. Cancer J; 19:79-89. https://doi.org/10.1097/PPO.0b013e3182801cf7

Submit your next manuscript to Journal of Angiotherapy published by EMAN Research

- Convenient online submission

- Thorough peer review

- No space constraints or color figure charges

- Immediate publication on acceptance

- Inclusion in Australian National Libraray and Google Scholar

- Both Open (80-100\% subsidized APC by ER) \& non-open access option

Submit your manuscript at https://publishing.emanresearch.org 